\title{
Gut microbiome in hematopoietic stem cell transplantation: patient- and treatment-related factors
}

\author{
Oleg V. Goloshchapov, Maxim A. Kucher, Alexey B. Chukhlovin \\ R. Gorbacheva Memorial Research Institute of Children Oncology, Hematology and Transplantology, St. Petersburg, Russia
}

Dr. Oleg V.Goloshchapov, R.Gorbacheva Memorial Research

E-mail: golocht@yandex.ru

Institute of Children Oncology, Hematology and Transplan-

tology, L. Tolstoy St 6-8, 197022, St. Petersburg, Russia

Citation: Goloshchapov OV, Kucher MA, Chukhlovin AB. Gut microbiome in hematopoietic stem cell transplantation: patientand treatment-related factors. Cell Ther Transpant 2018; 7(4): 16-28

\section{Summary}

Intensive cytostatic therapy is applied as a standard treatment in malignant disorders of hematopoiesis. Conditioning treatment before allogeneic hematopoietic stem cell transplantation (HSCT) causes both acute cellular immune deficiency and severe damage of gut epithelium, and massive antibacterial therapy lead to profound alterations of gut microflora composition. The aim of this review article was to specify environmental, genetic and treatment-related factors causing changes of gut microbiota in the course of intensive cytostatic therapy, delineating possible approaches to normalization of gut microbiome in HSCT. We discuss early experiments with germ-free organisms, describe common views on the "normal" human gut microbiota, its variability, and changes depending on age, dietary background and genetic predisposal between the main classes of gut microbiota, i.e., anaerobic Clostridia, and mostly aerobic Bacteroides, Proteobacteria. Changed composition and decreased biodiversity of gut microflora is regarded as a regular consequence of cytostatic and antibacterial therapies during the HSCT procedure. Role of enteric leakage, and effects upon immune system of host are considered in view of graft-versus-disease risk, as well as anti-cancer effects associated with altered composition of intestinal microbiota. Some genes affecting gut microbiota are discussed, e.g., effects of ATG16L1, PD-1, FUT2 and some other gene variants which may alter efficiency of HSCT.
Potential role of multiple gut viruses (virome) is known to much lesser degree, due to relative lack of data derived from next-generation sequencing (NGS) of bacteriophages and eukaryotic cell viruses.

In conclusion, many facts concerning gut microbiota require specific evaluation in human patients. E.g., a number of works was performed in order to correct altered gut microbiota in various intestinal syndromes, including specific probiotic strains of Lactobacteria, Bifidobacteria, Faecalibacterium prausnitzii, and more recently, fecal microbiota transplantation, also in the postHSCT dysbiosis. The main issue is that, when dealing with complex bacterial network of microbiota in clinical settings, we still do not know what exact microbial species (or classes) are producing effector molecules which modify immune response causing severe GvHD or changing the antitumor effects of immune therapy. To compare them with healthy subjects, the normal ranges should be established for distinct classes of intestinal microbiota within different age groups.

\section{Keywords}

Microbiome, intestinal, gut bacteria, virome, hematopoietic stem cell transplantation, cytostatic therapy, antibacterial treatment, microflora suppression, gut microbiota transplantation. 


\section{Introduction}

Intensive cytostatic therapy is applied as a standard treatment in malignant disorders of hematopoiesis. E.g., antitumor chemotherapy of leukemias is performed in several steps: remission induction, consolidating and supportive therapy. In cases of high-risk relapse, the patient is subject to allogeneic hematopoietic stem cell transplantation (HSCT), in order to inactivate residual cancer cells. During last 30 years, allogeneic HSCT was used in more than a million of cancer patients. As first step of treatment, they receive high-dose cytostatic therapy (conditioning treatment) which is usually combined with anti-infectious therapy. The conditioning therapy causes both acute cellular immune deficiency which recovers within months and, even, years [1]. Moreover, severe damage of oral and intestinal epithelium develops after intensive cytostatic treatment, and massive antibacterial therapy lead to alterations of gut microflora composition [2]. Pathogenic bacteria and their products migrate to blood plasma and may cause septicemia with detection of microbes and viruses in blood and on mucosal surfaces.

Allogeneic transplantation is generally performed from HLA-compatible familial or unrelated donor and is often accompanied by autoaggressive graft-versus-host disease (GVHD), an inflammatory epithelium lesion which also contributes to immune alterations and intestinal dysfunction. Such triple effect of cytotoxic drugs, allogeneic immune interactions, and immune deficiency should also change intestinal microbiota and its feedback effects upon host organism, including severe autoaggressive reactions [3].

The aim of our review is to specify biological and treatment-related factors causing changes of gut microbiota in the course of intensive cytostatic therapy and to delineate potential approaches to normalization for intestinal microbiome in such patients.

\section{Previous experience with germ-free mice}

The story began 50 years ago, when "gnotobiotic" (germfree) mice showed longer survival after irradiation at gut-damaging doses, compared to animals with normal gut microflora [4]. In a later study, the dogs subjected to lethal irradiation and bone marrow transplantation treated with antibacterial drugs proved to alleviate posttransplant complications after gut decontamination [5]. In 1980's, total or selective gut decontamination (e.g., neomycin, polymyxin B amphotericin B) to prevent posttransplant infections (and maintain colonization resistance) was implemented into routine practice of hematopoietic stem cell transplantation [6]. Modern schedules for gut decontamination in cytopenic and immunocompromised patients include different antibacterial, antifungal and antiviral drugs [7]. Prophylactic monotherapy with levofloxacin also seems to decrease rates of infection after intensive chemotherapy in cancer [8]. Fluoroquinolone- containing schedules and other conventional gut decontamination protocols seem to be suboptimal under current epidemiological environment [9]. These approaches should be directed for sparing necessary microbial diversity in gut microbiota and minimize risk for antibiotic-resistant infections.

\section{"Normal" and changed human gut microbiota}

Intestinal microbiota consists of myriads microorganisms, comprising a dynamic biological system functioning within a host organism. Human gut microbiota includes $>1000$ known microbial and fungal species [10]. Gut virome also contains hundreds viral species, both, phages and vertebrate viruses [11]. Over last years, possible role of the microbiota variety is described in a series of extensive review articles [12]. Generally, the major massive of intestinal microbiota may be classified into several big classes: anaerobic Clostridia and mostly aerobic Bacteroides, Proteobacteria. Anaerobic clostridial species seem to perform a big deal of metabolic events in normal state, producing some essential metabolites for the host organism, e.g. short-chain fatty acids necessary for enterocyte survival and regulating immune effects in the host. Common changes in main classes of microbiota are associated with different gastrointestinal disorders, e.g., inflammatory bowel diseases [13].

\section{Enteric permeability, microbial translocation and effector molecules}

Viable intestinal microbiota produces big amounts of biologically active compounds which may under certain conditions penetrate from intestinal lumen via enteric wall to blood and lymph vessels. Live intestinal bacteria are thought to cross enteric/blood barrier in cases of intestinal damage caused, e.g., by intensive cytostatic treatment, or in severe immune deficiency as it is seen in AIDS patients being a sign of the so-called bacterial translocation [14]. Bacterial components and metabolites in blood serum are known clinical markers of the patients with septicemia [15]. E.g., lipid A (lipopolysaccharide, LPS) is a component of endotoxin from Gram-negative bacteria, being detectable in blood plasma or urine. The LPS presence in serum suggests blood contamination with these bacteria or their fragments. Other plasma markers of septicemia are produced by the host cells (soluble CD14; LPS-binding protein etc.). LPS in clinical material is detected by in vitro test with Limulus lysate, whereas lipid A may be found and quantified by means of ELISA or mass-spectrometry.

The 2,3-indoxyl sulfate (IS) is a useful marker of a gut dysbiosis, being produced by gut bacteria from tryptophan [16]. It is determined quantitively in blood plasma or urine by means of high-performance liquid chromatography/mass spectrometry. High IS amounts in blood are found in severe infections, intestinal dysbiosis, leakage of intestinal or hepatic barriers. Increase in other microbial metabolites, p-cresyl sulfate and trimethylamine-N-oxide is of similar diagnostic significance. By the contrary, decreased blood citrulline may be a sign of intestinal damage, since it is synthesized by enterocytes [17].

\section{Microbiota and immune response: APC and Th17 T cell network}

Microbial and viral antigens, while penetrating mucosae, regional microvessels and lymph nodes, elicit local and regional polyclonal B- and T cell-mediated immune responses, thus being a key factor of normal maturation and functioning of immune system. Important role of intestinal microflo- 
ra in development and tuning of general immune response in humans, especially, in childhood, is extensively discussed in a number of review articles [18].

The mechanisms of immune maturation proceed via Th17 and a chain of other signaling factors. Composition of gut microbiota and HLA antigens in host organism are also mutually dependent, both in normal and diseased persons, at least, in children, upon education of their immune system [19].

Hence, there are bidirectional relations between intestinal microbiota and the host immune system which may sufficiently modify the gut microbiome, along with immediate effects of cytostatic therapy, as well as long-term clinical outcomes, especially during hematopoietic stem cell transplantation (HSCT), due to minor differences in HLA antigens between donor and recipient.

\section{Individual diversity of gut microbi- ota with age and dietary factors}

During pregnancy, fetal intestine is sterile, being influenced by a number of external and internal factors $[20,21]$. The extrinsic factors are - geographic area, maternal and surrounding environment bacteria, the way of childbirth - natural or by caesarean section, hygiene measures, feeding habits, drug therapies. As usual, colonizing bacteria derive from the mother - mainly vaginal and intestinal microbiota, breast milk and surrounding environment [22].

The intrinsic factors include neonatal genetics, bacterial mucosal receptors and interactions, intestinal $\mathrm{pH}$ and secretions, and immune response [24, 25].

One of the most important factors during the first months of life affecting the qualitative and quantitative composition of the microbiota is the fact of breast-feeding, which in addition to the energy function, provides immunoregulation [26], the digestive system functioning due to the presence of growth factors, cytokines, immunoglobulins and digestive enzymes in its composition [27].

During the first and second year of life, differences between breast- and formula-fed infants are lost [28]. But short- and long-term effects of breast-feeding are much better in comparison to formula-fed infants reducing the incidence of allergic and autoimmune diseases [29], inflammatory bowel diseases, cardiovascular diseases, obesity, type-2 diabetes $[30,31]$.

In the future, microbiota composition changes and its functional activity depend on nutrition features [32]. For example, the commitment to a Western diet, which typically consist of red meat, animal fat, high sugar and low fiber food, leads to an increased number of Bacteroides phyla (mainly mucin-degradating bacteria) and Ruminococcus [33], reduced number of obligate bacteria, especially in the elderly [34]. While diet rich in fiber correlate with larger bacterial diversity [35] and provide more functional microbiota activity, the degree of immunoregulation and cancer prevention [36].

One of the important questions is the impact of probiotics in the setting of availability to change microbiota characteristics and functioning is still controversial and depends on diagnosis and initial bacteria profile. Probiotics are defined as «live microbial food supplements or components of bacteria which have been shown to have beneficial effects on human health» and generally contain bacteria belonging to the genera Lactobacillus and Bifidobacterium. It is shown that probiotics may have positive influence on immune functions, blood cholesterol decrease, vitamin synthesis, anti-cancerogenesis and anti-bacterial effect [37]. On the other hand,

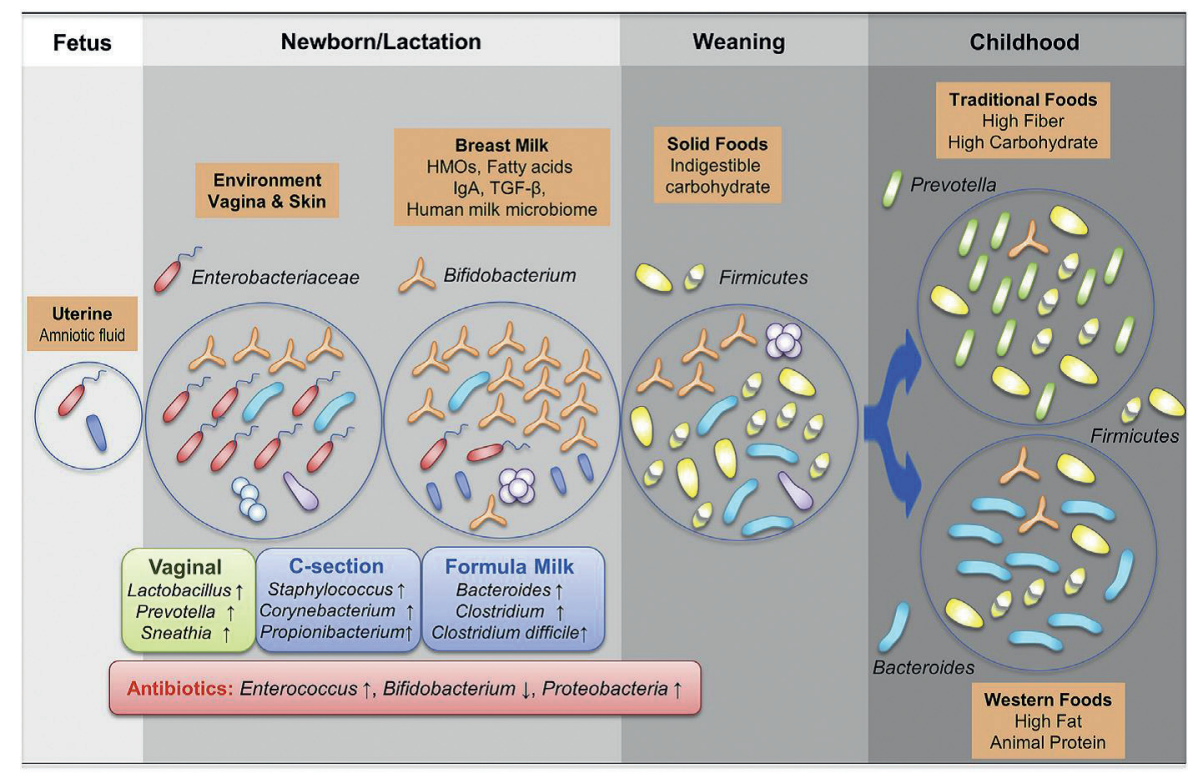

Figure 1. Overview of age-dependent human gut microbiota colonization (Note enrichment with anaerobic Firmicutes with high-fat and protein diet). Diversity of the gut microbiota increases with age until it becomes a stable adult microbiota. (Tanaka, Nakayama, 2017) 
there is data indicating that probiotics are unable to colonize intestine for a long period of time, and have less efficacy in treatment of antibiotic associated diarrhea [38].

Some specific host-microbiota relations were found by a joint team from Netherlands and Russia who performed metagenomic sequencing in 1,514 subjects [39]. Using GWAS approach, they have found significant associations of 9 human genome loci with microbial taxonomies and 33 loci with microbial pathways, including genome-wide significance for the C-type lectin molecules CLEC4F-CD207 at 2p13.3 and CLEC4A-FAM90A1 at 12p13, and association of a functional LCT SNP with the Bifidobacterium genus $\left(\mathrm{P}=3.45 \times 10^{-8}\right)$. These findings suggest an evidence of a gene-diet interaction for the regulation of gut Bifidobacterium population.

However, an extensive genotype and microbiome study from the same workers based on the samples from 1,046 healthy individuals of different ancestry who shared a relatively common environment has shown that the host genetics does not sufficiently contribute to the microbiome composition [40]. Important similarities are found in the microbiota composition from genetically unrelated individuals who have common household. An estimated value of $>20 \%$ of the inter-person microbiome variability is shown to be associated with dietary factors, drugs and individual anthropometry.

Indeed, despite sufficient effects of some gene variants, an impact of non-heritable factors, such as diet, seems to predominate the effects of host genetic background [41].

\section{Microbiota affection by antimicro- bial and anticancer therapy}

Intensive cytostatic therapy is universally accompanied by leucopenia an temporary cellular immune deficiency, thus causing activation of many opportunistic infections [42]. E.g., the Clostridium difficile infection is considered an important factor of intestinal disorders and general immune suppression in childhood [43]. The antibiotic-resistant bacterial strains occur at higher rate in gut, as seen from results of routine bacteriological studies.

Over last years, numerous studies show depletion of distinct bacterial groups as shown by next-generation sequencing. Load and composition of fecal microbiota were studied immediately after treatment in 21 patients, who received broad-spectrum antibiotics such as fluoroquinolones and b-lactams [44]. Fecal samples were collected from all participants before treatment and one week after for microbial load and community composition analyses by quantitative PCR and pyrosequencing of the 16S rRNA gene. The study has shown a decrease in total bacterial load, and ratio of sufficient anaerobic bacteria. At the phylum level, the treatment with antibiotics increased the Bacteroidetes/Firmicutes ratio, as well as at the genera levels, mostly, due to Lachnospiraceae and Blautia exhaustion.

By contrary, experimental treatment of mice with cyclophosphamide is associated with depletion of Bacteroidetes in gut microbiota, along with accumulation of potentially harmful bacteria [45].

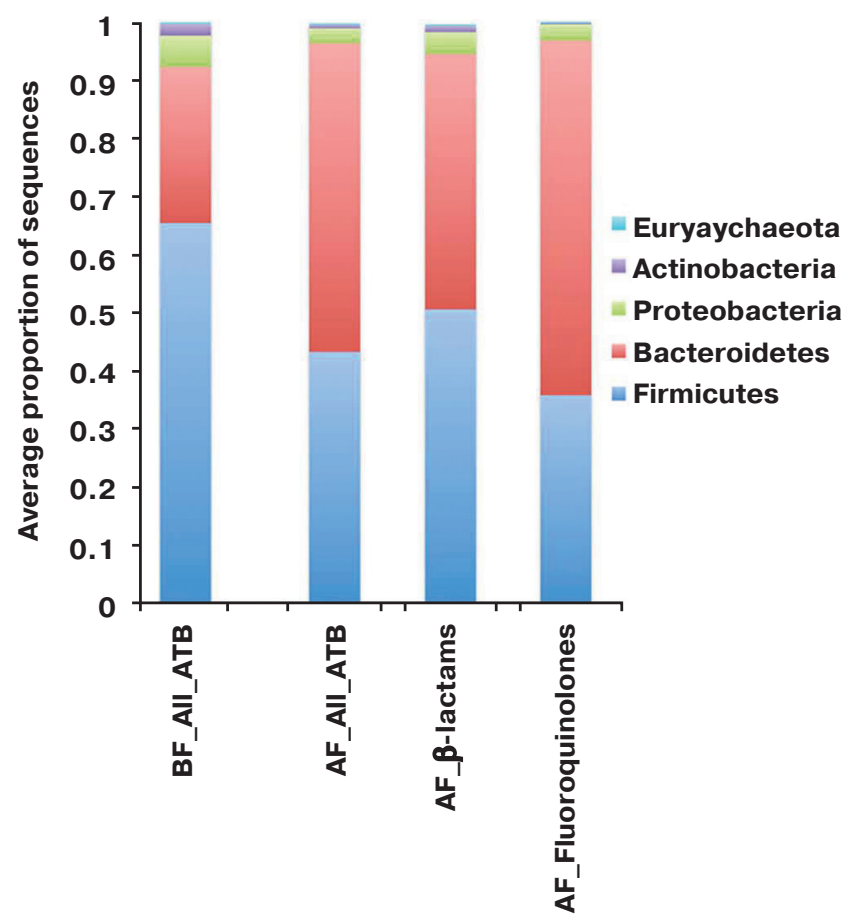

Figure 2. Microbial composition at the phylum level based on 165 rRNA gene sequences. BF = Before treatment; $\mathrm{AF}=$ After treatment; $\mathrm{ATB}=$ Antibiotics. For all antibiotics $\mathrm{N}=21$; for b-lactams $\mathrm{N}=11$; for fluoroquinolones $\mathrm{N}=10$ (Panda et al., 2017)

However, the question remains open, how combined antibacterial/anticancer therapy (e.g., cyclophosphamide) will affect intestinal microbiota in patients with malignancies and affect clinical outcomes. To this purpose, future clinical studies are required. Disturbed composition of gut microflora may be accompanied by remarkable functional changes of both anti-infectious and antitumor immunity [46].

\section{Gut microbiota and acute GrHD}

Acute GvHD is a common and often life-threatening HSCT complication caused by cytotoxic effects of donor $\mathrm{T}$ cells against skin and gut epithelium of the patients. GvHD severity may vary from grade 1 (mild reaction) to III-IV. A lot of genetic factors are shown to predispose for severe GvHD. Moreover, some infectious factors seem to cause or modify clinical course of GvHD, such as reactivation of CMV or EBV $[1,42]$.

Possible role of gut bacteria as a risk factor for GvHD is now questioned. E.g., antibacterial and cytostatic therapy before HSCT causes depletion of Clostridiales order, especially, Blautia genus. Reduction in these clostridiococci proved to be associated with higher GvHD mortality in these patients [47]. Different changes of gut microbiota and relevant immune mechanisms promoting GvHD in alloHSCT patients were recently summarized [48, 49]. 


\section{Host pleiotropic genes: their presu- mable effects upon gut microbiota}

After initial optimism on predisposing role of functional gene variants in various disorders, some cautions appeared, when interpreting possible changes in genetic immune regulation, e.g., after hematopoietic stem cell transplantation. The problem is that, besides numerous gene polymorphisms of protein-encoding segments, one should consider effects of other single-nucleotide polymorphisms (SNPs) in regulatory elements and small molecules, like as microRNAs (miRNAs), and their interactions. Hence, phenotypic effects for most SNPs may be rather blurried and not reproducible when studied in different populations and clinical series, as reviewed by Gam et al. [50].

About 100 genes or allelic variants, mostly those controlling immune functions of Th1, Th2, and Th17 effector populations, were shown to be associated with susceptibility with inflammatory bowel diseases (IBD), as reviewed by Basso et al. [51].

However, at the present time, current GWAS studies allowed to find correlations between genotype and phenotype for a number of pleiotropic human genes which modify quite different disorders, e.g., lipid disturbances and immune diseases [52]. A detailed genotype-phenotype analysis has revealed shared effects common for gut immune disorders (e.g., Crohn's disease, ulcerative colitis, celiac disease etc.), and lipid biology. These genes concern several shared pathways including glycosphingolipid synthesis (e.g. FUT2) and intestinal host-microbe interactions (e.g. ATG16L1).

\section{ATG16Ll and gut pathology}

The ATG16L1 gene encodes an autophagy protein which is produced in many cell types, including antigen-presenting cells. Among different polymorphisms, a single variant of ATG16L1 (rs2241880, T300A) may predispose for development of Crohn's disease. The protective ATG16L1 allele encodes threonine at amino acid position 300 (ATG16L1³00T), whereas ATG16L1*300A encoding alanine confers higher risk for development of Crohn's disease [53]. In human intestinal epithelium, the Crohn's disease-associated ATG16L1 coding variant shows impaired capture of internalized Salmonella within autophagosomes. Thus, we propose that the association of ATG16L1*300A with increased risk of Crohn's disease is due to impaired interactions with bacterial and decreased bacterial capture by autophagy.

ATG16L1 in the intestinal epithelium was shown to prevent loss of Paneth cells and exaggerated cell death in animal models of experimental inflammatory bowel disease, and, interestingly, allogeneic hematopoietic stem cell transplantation. The mutant Atg16L1HM mice are more affected by graft-versus-host disease (GVHD) after allo-HSCT. Hence, ATG16L1 seems to keep the intestinal barrier by inhibiting epithelial cell death [54].

An elegant study was performed by Sadabad et al. [55]. The inflamed and non-inflamed sites of ileal mucosa from ATG16L1-typed patients with Crohn's disease were studied, with respect to microbiota composition at these sites. Inflamed ileal tissue of patients homozygous for the ATG16L1 protective allele showed decreased numbers of Bacteroidaceae and Enterobacteriaceae and increased Lachnospiraceae. Upon in vitro assays, the monocytes homozygous for the ATG16L1 risk allele showed impaired killing of pathogenic E.coli under inflammatory conditions. However, the ATG16L1 allele did not affect the bacterial composition in the non-inflamed ileal tissue. The authors suggest that the host cellular immunity seems to regulate the gut microbiota composition by genetic mechanisms.

Another study [56] has shown that the common GG variant of ATG16L1 interfered with the production of IL-1 $\beta$, which was highly induced in PBMCs from patients with GG genotype by exposure to pathogenic E.coli. The authors have also observed that the T300A variant in patients with $\mathrm{CD}$ strongly increases the risk for complicated fistulizing disease, and significantly affects antibacterial responses in vitro. Meanwhile, any studies on the role of ATG16L1 in HSCT are absent in available literature

\section{PD-1 gene}

The PD-1 and its ligands (PD-1L) represent a system of costimulatory signal proteins that regulate activation and deactivation of T cells, modulates immune response to infectious pathogens and tissue antigens, thus mediating some autoimmune conditions [57]. PD-1 is encoded by the PDCD1 gene, being expressed on many cell types in humans. Hence, its expression may sufficiently influence both antiinfectious and antitumor response in HSCT patients.

PD-1 is a coinhibitory receptor that is inducibly expressed on T cells and B cells, natural killer T cells, and monocytes. Carriers of the A allele express lower levels of PD-1 receptor on the Treg cells (CD4+CD25+ cells) [58]. The variable G/A site is located in an intronic enhancer (intron 4, position 7,146) within a DNA-binding site for the RUNX1 transcription factor. Appropriate gene variant was called PD-1.3 (rs11568821). The common variant allele A is suggested to contribute to an aberrant transcriptional regulation of PD-1 in SLE and other autoimmune diseases.

However, typing of the PDCD1 gene may be also informative in transplantation settings. I.e., Hoffmann et al. [59] have genotyped the PD-1 variants in 469 seropositive kidney graft recipients and showed a significant correlation between CMV reactivation and $\mathrm{PD}-1.3$ allele $\mathrm{A}$ which proved to be associated with CMV infection posttransplant. Interestingly, inclusion of functional IL12B 3'UTR variants increased this association. In other study, the PD-1.3 variant was typed in 1119 kidney recipients and 181 lung recipients [60]. In 481 kidney transplants, the A allele carriers showed less common kidney graft failure than the $\mathrm{G}$ homozygotes. Moreover, evaluation of 85 lung recipients has shown similar results, i.e., the A-carriers had longer survival, and better function of transplanted organ. In addition, the, AA recipients had a stronger anti-CMVpp65 T-cell response than the GG-typed patients.

Effects of donor PD-1 variants upon clinical course of postHSVCT period were presented by Santos et al. [61]. The workers have found an increased risk of grades II to IV graft- 
versus-host disease (GvHD) when the grafts were used from the donors homozygous for the A allele of the rs11568821 SNP. Those subjects comprised only 30 cases out of 1500 (ca.1.5\%). Meanwhile, the PD-1.3 G>A genotype of the donor was not associated with overall survival or relapse incidence. Hence, the PD-1 gene polymorphism effects seemed to affect, mainly the GVHD immune aspect in this extensive study.

Association between PD-1 variants and sepsis outcomes was also found by Mansur et al. [62] who studied the rs11568821 SNP in 219 patients with severe sepsis. The 3-month mortality proved to be much higher for the GG group than for A allele carriers, with increased scores of multiple organ failure.

A number of novel inhibitors of PD-1 or PD-1 ligand are now introduced into clinical practice. In this respect, certain probiotic gut bacteria are considered a sufficient modifying factor when treating malignancies with these immune checkpoint inhibitory drugs [63].

\section{FUT2 gene}

This gene encodes fucosyl transferase, an enzyme adding a fucose residue, thus producing secretor state of $\mathrm{H}$ blood group antigen. This surface molecule also serves as a receptor for some intestinal viruses, thus the secretor state of FUT2 largely determines susceptibility to rotavirus and some other gut viral infections [64].

Additional evidence for the FUT2 gene polymorphism as a factor of rotavirus infection was found in the study by Günaydin et al. [65]. Rotavirus-specific antibody titers proved to be significantly higher in persons with secretor FUT2 variants than in non-secretors.

A special meta-analysis (about 10,000 cases) as revealed a strong association between the rs601338 (W154X) in the FUT2 gene [66]. The children with the A allele, which results in a truncated FUT2 protein, had lower risk of diarrhea, presumably, due to decreased numbers of cell receptors for pathogenic viruses (e.g., rotavirus).

To characterize metabolic effects of FUT2 gene polymorphism upon the mucosal ecosystem, a simultaneous assessment of microbiome, meta-proteome and meta-metabolome was performed in 75 endoscopic lavage samples from the cecum and sigmoid from 39 healthy subjects with different FUT2 gene status (rs601338 G>A). The general metagenomic analysis revealed perturbations of energy metabolism in the microbiome from the non-secretor persons, i.e., enhanced carbohydrate and lipid metabolism, altered glycan biosynthesis and depleted amino-acid metabolism. Similar changes were reproduced in mice carrying the FUT2(-) genotype [67].

However, the associations between FUT2 secretor genotype and gut microbiota diversity were not confirmed by a recent study performed in 1190 healthy persons since no correlations were revealed for alpha-diversity, or microbial composition assessed by NGS approach [68].

\section{Other human genes potentially changing gut microbiota}

Several years ago, the group by Holler et al. [69] has discovered a distinct correlation between certain polymorphisms of TLR and NOD2/CARD gene and high incidence of acute intestinal GVHD after HSCT. These genes encode specific pattern-recognition receptors for bacterial antigens and mediate acute inflammation switched by innate mechanisms. Special studies of intestinal biopsies from the GVHD patients have shown loss of protective CD4 T cells which was more pronounced in carriers of NOD2/CARD15 gene variants [70].

Relations of NOD/CARD system and other gut disorders is also confirmed by the results of Hrnčírová et al. [71] concerning distinct associations between Crohn's disease and some gene variants of CARD15/NOD2 gene.

Associations between NOD/CARD polymorphisms and posttransplant infections were studied by Grube et al. [72]. The authors found a significant association between the presence of donor NOD2 SNP13 (3016_3017insC) and the incidence of septic shock $(\mathrm{P}<002)$. In multivariate analysis, donor NOD2 SNP13 appeared as an independent risk factor for the incidence of septic shock after allo-SCT.

In a Chinese study of sepsis cohort, the authors did not found any significant associations for either TLR gene polymorphisms (rs4986790 or rs4986791) with sepsis susceptibility in total analysis in any genetic models [73].

Less significant (minor) differences for other gene variants may be obtained in large study groups, found due to big statistics. E.g., an international group has tested 10,523 IBD cases and 5,726 non-IBD controls by means of GWAS approach using the Illumina technique [74]. The workers have revealed a highly significant association between between Crohn's disease and a missense variant in the zinc transporter solute carrier family 39, member 8 protein (SLC39A8 Ala391Thr, rs13107325). The association of this SNP with microbiota was assessed in 338 colonic mucosal lavage samples using $16 \mathrm{~S}$ rRNA sequencing. The Crohn's disease risk allele proved to be associated with altered colonic mucosal microbiome in healthy controls and the patients $(\mathrm{p}=0.0009)$. Among major bacterial taxa of colon microbiota, the SLC39A8 Thr391 allele carriers exhibited significant depletion of, e.g., Coprococcus, Roseburia, Lachnobacteria, Faecalibacterium prausnitzii and Ruminococcus gnavus in Crohn's disease patients.

\section{Pro- and anti-cancer effects asso- ciated with altered composition of intestinal microbiota}

Over last years, abnormal intestinal microbiota is recognized as a factor of cancer treatment efficiency and, especially, in cancer immunotherapy [75]. Potential associations between altered gut microbiota and clinical outcomes of malignancies are studied. 
E.g., colonic presence of Fusobacterium nucleatum correlates with increased risk for colorectal cancer, and its overpresentation in stool is shown to be associated with higher resistance of this tumor to chemotherapy [76].

In murine experiments, it was shown that prevalence of some intestinal Gram-positive bacteria may increase efficiency of cytostatic tumor treatment, and, vice versa, antibacterial therapy eliminating Gram(+) microbes caused a decreased response of the tumors to cyclophosphamide treatment [77]. The authors suggest this biological effect to be mediated by the Th17 T cell network which is switched by gut microflora-derived antigens. Appropriate clinical study was performed in patients with chronic lymphocytic leukemia (CLL) receiving cytostatic therapy [78]. A subgroup of patients treated with antibiotics against Gram-positive bacteria showed earlier progression of malignancy and decreased long-term survival.

Vice versa, predomination of a bacterial population represented mostly of Eubacterium limosum correlated with decreased risk of relapse/progression posttransplant [79]. Eubacterium limosum belongs to anaerobic bacteria producing butyric and other short-chain fatty acids which are considered to support viability and functioning of gut epithelium and local immune response [80].

Moreover, many attempts were made to correct or replace the damaged gut microbiota with specific strains of Lactobacteria, Bifidobacteria, Faecalibacterium prausnitzii, or other probiotics [81], causing partial clinical responses in the patients with immune disorders. Probable potentiation of immune checkpoint inhibitory (anti-PD-1) therapy will be achieved, using distinct probiotic gut bacteria [63].

\section{Probiotics and fecal transplanta- tion post-HSCT}

Fecal transplantation as a tool for microbiota substitution was proposed centuries ago. However, clinical indications for FMT and microbial markers of FMT efficiency were developed within last 2-5 years. These indications are based on the integral assessment of gut microbial spectrum performed by different NGS techniques allowing to and assess ratio between distinct bacterial classes and genera [82].

Fecal microbiota transplantation (FMT) is now proposed as a substitution correcting therapy in the disorders characterized by shifts in microbial species, or other disturbances of the gut microbiota (Crohn's disease, nonspecific ulcerous colitis, persistent C.difficile infections). Over recent years, sporadic small studies of FMT after hematopoietic SCT were performed in several patients with steroid-resistant intestinal GVHD by the groups from Japan and Netherlands, showing safety and satisfactory clinical efficiency of the treatment method $[83,84]$. At our BMT clinics, we have performed small studies with 11 patients who underwent allogeneic HSCT and suffered with multiresistant microbial infections [85]. In most of the patients treated by FMT, fast clinical response was observed, along with positive dynamics of microbial flora in their stool samples. Our further studies are aiming to extend indications for FMT usage after allo-HSCT, in order to treat bacterial complications and immune disturbances (i.e., graft-versus-host disease) which sufficiently depends on gut microbiota changes [86].

Appropriate clinical trials on the fecal microbiota transplants (FMT) have been carried out since 2014, according to the Clinical trials.gov registry, mostly, in Crohn's disease, non-specific ulcerous colitis, resistant C.difficile infection. A total of 46 FMT trials for various clinical indications are registered in this field, mostly for the phase I (safety and tolerance).

\section{Gut virome in normal state and after HSCT}

\section{Bacteriophages}

Only limited number of works concerns gut virome as a big variety of bacteriophages and eukaryotic viruses living in human cells. A competent review by Columpsi et al. [87] highlighted the issue of the intestinal bacteria and phage equilibrium, probability of eubiosis shifts, due to the phage lytic effects, thus causing health disorders. Moreover, the products of bacterial lysis and viral antigens could potentially trigger some adverse inflammatory modulations. There is a large heterogeneity of phages, which are infecting, mostly, specific bacterial classes and are difficult for appropriate taxonomic classification. Ongoing epidemiological studies of intestinal phages are mostly performed by the NGS method, i.e., parallel sequencing of multiple small fragments of DNA followed by in silico alignment and reconstruction of multiple genomes, in order to identify known and novel phage sequences.

A recently described intestinal crassPhage with in silico estimated properties, however, with unknown incidence and epidemiological features was described several years by means of modern NGS technique and in silico digital characterization of this, previously unknown phage which is probably living in Bacteroides and is detectable in ca. $73-77 \%$ of humans, is able to vertical transmission [88]. Moreover, the authors have shown its transmission to the recipient during fecal microbiota transplantation in C.difficile infection, thus showing an opportunity of tracing its migration pathways.

\section{Eukaryotic cell viruses}

Generally, a number of RNA and DNA viruses living in eukaryotic intestinal cells are detected in normal human gut, including rotavirus, astrovirus, calicivirus, norovirus, hepatitis E, adenoviruses etc. [87]. Moreover, quite recently, multiple "novel" RNA and DNA viruses were identified in gut microbiota by their specific gene sequences, e.g., Picornaviridae, Coronaviridae, Astroviridae, Parvoviridae members, using high-coverage NGS approach [89].

Clinical viral infections and reactivation of different intestinal viruses were extensively studied in hematopoietic stem cell and organ transplantation, including adenovirus, bocavirus, coronavirus, human herpesvirus-6, lymphocytic choriomeningitis virus, measles, mumps, metapneumovirus, parainfluenza, rotavirus, etc. [90].

Routine clinical protocols for hematopoietic stem cell transplantation include weekly or bi-weekly multiple PCR 
screening for herpesviruses (cytomegalovirus, Herpes simplex, Epstein-Barr virus) and, especially, adenovirus for the first 1-2 months posttransplant which correlate with different life-threatening complications [91]. Virus persistence in blood or stool may require further monitoring of viral load and consider the role of pathogen in intestinal disorders (i.e., prolonged diarrhea, intestinal GVHD). A sufficient role of altered gut virome in HSCT was shown by Legoff et al. [48]. The authors have undertaken a global NGS study of gut microbiota in HSCT patients over different time points and have found increased proportion of picobirnavirus (PBV) sequences in stool of the patients who later developed acute enteric GVHD. The increased PBV levels were revealed both before and up to 1 month posttransplant.

Interestingly, filterable (potentially, viral) substances of gut microbiota may be also effective in fecal transplantation. A German group [92] has used stool samples passed through Seitz filters, thus removing all native microbes, leaving presumably viral particles and some bacterial components. These fluid preparations were delivered to intestines of the patients with C.difficile infection and have produced good clinical effect, despite absence of intact bacteria in the fecal transplant. Effect of such treatment, if it will be reproduced, may be dependent on bacteriophages and human viruses present in the cell-free fluid used by the workers.

Potential role of bacteriophages in posttransplant conditions is suggested in the review article by Górski et al. [93]. This paper contains a collection of data on positive immune-mediated effects of intestinal bacteriophages upon intestinal epithelial cells, thus, probably, causing mitigation of graftversus-host disease in humans. Worthy of note, a special study with FMT in C.difficile infection has shown that the donor-derived bacteriophages (specifically, Caudovirales) were expanded to larger degree in the patients responding to FMT than in those who did not [94]. Vice versa, the FMT recipients who received donor faeces with higher Caudovirales abundance were successfully treated with FMT. Appropriate studies in HSCT setting would be of sufficient value in future, thus evaluating role of the phage component on FMT effects.

\section{Future prospects}

Despite good current knowledge on sufficient role of intestinal microbiota in HSCT setting, some issues remain unresolved.

First of all, most studies on positive effects of microbiota were performed in experimental models, thus requiring specific evaluation of these facts in human patients. Secondly, when dealing with complex bacterial network of microbiota in clinical settings, we still do not know what exact microbial species (or classes) are producing effector molecules modifying human immune response leading to severe GvHD or associated antitumor effects of immune therapy. To compare them with healthy subjects, the normal ranges should be established for distinct classes of intestinal microbiota within different age groups. Thirdly, the qualitative and quantitative ranges of normal intestinal microbiota should be specified by classical bacteriological and immunological diagnostics accomplished with multiplex DNA diagnostics (multiplex
PCR and next-generation sequencing) of stool samples from healthy persons. As a result, the new molecular targets could be suggested for improved immune therapy of oncological diseases, especially, in childhood. A special issue bears on proven combined effects of the antibacterial/anticancer therapy (e.g., cyclophosphamide) upon intestinal microbiota, with appropriate consequences for early HSCT complications and risk of relapses in human leukemias, lymphomas and some pediatric malignancies.

Due to absence of notable clinical recovery in HSCT from the probiotics treatment, one may, at this step of clinical research, propose a full-microbiota replacement for treatment of severe intestinal dysbioses, i.e., introduction of normal mixed donor microbiota to the gastrointestinal tract, aiming for rapid recovery of normal microbial composition. Such experimental treatment option is a kind of biotherapy which is now effectively used in the patients with persistent C.difficile infection, intestinal bowel diseases etc. Hence, fecal microbiota transplantation is feasible in HSCT patients, first of all in antibiotic-resistant colitis, or steroid-insensitive GVHD. Our pilot data suggest safety and certain clinical efficiency of this approach, however, requiring further observations in larger groups.

\section{Conflicts of interest}

None of the authors declare any conflicts of interest.

\section{References}

1. Pankratova OS, Chukhlovin AB. Time course of immune recovery and viral reactivation following hematopoietic stem cell transplantation. Cellular Therapy and Transplant. 2016; $5(4): 32-43$.

2. Jenq RR, Taur Y, Devlin SM, Ponce DM, Goldberg JD, Ahr KF, Littmann ER, Ling L, Gobourne AC, Miller LC, Docampo MD, Peled JU, Arpaia N, Cross JR, Peets TK et al. Intestinal Blautia is associated with reduced death from graftversus-host disease. Biol Blood Marrow Transplant.2015; 21:1373-1383.

3. Kolb H-J, Weber D, Pinto Simões B, Holler E. Infection and GVHD. Cell Ther Transplant. 2018; 7(1): 8-17.

4. Matsuzawa T. Survival time in germ-free mice after lethal whole body x-irradiation. Tohoku J Exp Med. 1965;85:257263.

5. Vriesendorp HM, Heidt PJ, Zurcher C. Gastrointestinal decontamination of dogs treated with total body irradiation and bone marrow transplantation. Exp Hematol. 1981; 9(9):904-916.

6. Guiot HFL, Van Furth R. Selective decontamination in bone marrow transplant recipients. Epidemiol. Infect, 1992, $109,349-360$

7. Taplitz RA, Kennedy EB, Bow EJ, Crews J, Gleason C, Hawley DK, Langston AA, Nastoupil LJ, Rajotte M, Rolston KV, Strasfeld L, Flowers CR. Antimicrobial prophylaxis for adult patients with cancer-related immunosuppression: ASCO and IDSA Clinical Practice Guideline Update. J Clin Oncol. 2018; JCO1800374. doi: 10.1200/JCO.18.00374. 
8. Alexander S, Fisher BT, Gaur AH, Dvorak CC, Villa Luna D, Dang H, Chen L, Green M, Nieder ML, Fisher B, Bailey LC, Wiernikowski J, Sung L; Children's Oncology Group. Effect of levofloxacin prophylaxis on bacteremia in children with acute leukemia or undergoing hematopoietic stem cell transplantation: A randomized clinical trial. JAMA. 2018;320(10):995-1004.

9. Horton LE, Haste NM, Taplitz RA. Rethinking antimicrobial prophylaxis in the transplant patient in the world of emerging resistant organisms - where are we today? Curr Hematol Malig Rep. 2018;13(1):59-67.

10. Sankar SA, Lagier JC, Pontarotti P, Raoult D, Fournier PE. The human gut microbiome, a taxonomic conundrum. System Appl Microbiol. 2015, http://dx.doi.org/10.1016/j. syapm.2015.03.004

11. Legoff J, Resche-Rigon M, Bouquet J, Robin M, Naccache SN, Mercier-Delarue S, Federman S, Samayoa E, Rousseau C, Piron P, Kapel N, Simon F, Socié G, Chiu CY. The eukaryotic gut virome in hematopoietic stem cell transplantation: new clues in enteric graft-versus-host disease. Nature Medicine. 2017, 23(9):1080-1085.

12. Tang WHW, Kitai T, Hazen SL. Gut Microbiota in Cardiovascular Health and Disease. Circ Res. 2017; 120(7): 1183-1196.

13. Mancabelli L, Milani C, Lugli GA, Turroni F, Cocconi D, van Sinderen D, Ventura M. Identification of universal gut microbial biomarkers of common human intestinal diseases by meta-analysis. FEMS Microbiology Ecology, 93, 2017, fix153

14. Marks MA, Rabkin CS, Engels EA, Busch E, Kopp W, Rager H, Goederta JJ, Chaturvedi AK. Markers of microbial translocation and risk of AIDS-related lymphoma. 2013, AIDS;27:469-474

15. Riedel S, Carroll KC. Laboratory detection of sepsis: biomarkers and molecular approaches. Clin Lab Med 2013;33:413-437.

16. Leong SC, Sirich TL. Indoxyl Sulfate-Review of Toxicity and Therapeutic Strategies. Toxins (Basel). 2016;8(12). pii: E358.

17. Barzał JA, Szczylik C, Rzepecki P, Jaworska M, Anuszewska E. Plasma citrulline level as a biomarker for cancer therapy-induced small bowel mucosal damage. Acta Biochim Pol. 2014;61(4):615-631.

18. Shi N, Li N, Duan X, Niu H. Interaction between the gut microbiome and mucosal immune system. Mil Med Res. 2017; 4:14. doi:10.1186/s40779-017-0122-9

19. Marietta E, Rishi A, Taneja V. Immunogenetic control of the intestinal microbiota. Immunology, 2015; 145, 313-322.

20. Mackie RM, Sghir A., Gaskins HR. Developmental microbial ecology of the neonatal gastrointestinal tract. Am J Clin Nutr. 1999; 69:1035-1045.

21. Fanaro S, Chierici R, Vigi V. Intestinal microflora in early infancy: composition and development. Acta Paediat. 2003; Suppl 91:48-55.
22. Guaraldi F, Salvatori G. Effect of breast and formula feeding on gut microbiota shaping in newborns. Front Cell Infect Microbiol. 2012; 2(94):1-4.

23. Tanaka M, Nakayama J. Development of the gut microbiota in infancy and its impact on health in later life. Allergol Int. 2017; 66:515-522.

24. Penders J, Thijs C, Vink C, Snijders B, Kummeling I, van den Brandt PA, et al. Factors influencing the composition of the intestinal microbiota in early infancy. Pediatrics. 2006; 118:511-521

25. Fallani M, Young D, Scott J, Norin E, Adam R, Aguilera $\mathrm{M}$, et al. Intestinal microbiota of 6-week-old infants across Europe: geographic influence beyond delivery mode, breast-feeding, and antibiotics. J Pediat Gastroenterol Nutr. 2010; 51:77-84.

26. Praveen P, Jordan F, Priami C, Morine MJ. The role of breast-feeding in infant immune system: a systems perspective on the intestinal microbiome. Microbiome. 2015. 3:41 DOI 10.1186/s40168-015-0104-7.

27. Le Huerro-Luron I, Blat S, Boudry S, Breast- vs formula-feeding: impacts on the digestive tract and immediate and long-term health effects. Nutr Res Rev. 2010; 23:23-36.

28. Stark PL, Lee A. The microbial ecology of the large bowel of breast-fed and formula-fed infants during the first year of life. J Med Microbiol. 1982;15:189-203.

29. Akobeng A.K., Ramanan AV., Buchan I., Heller RF. Effect of breast feeding on risk of coeliac disease: a systemic review and meta-analysis of observational studies. Arch Dis Child. 2006; 91:39-43.

30. Kramer MS. Breast feeding and allergy: the evidence. Ann Nutr Metab. 2011;59:20-26.

31. Brown K., DeCoffe D., Molcan E., Gibson DL. Diet-induced dysbiosis of the intestinal microbiota and the effects of immunity and disease. Nutrients. 2012;4:1095-1119.

32. Bibbo S, Ianiro G, Giorgio V, Scaldaferri F, Masucci L, Gasbarrini A, Cammarota G. The role of diet on gut microbiota composition. Eur Rev Med Pharmacol Sci. 2016;20:47424749

33. Mukhopadhya I, Hansen R, El-Omar EM, Hold GL. IBD - what role do Protebacteria play? Nat Rev Gastroenterol Hepatol. 2012; 9:219-230.

34. Claesson MJ, Cusack S, O'Sullivan O, et al. Composition, variability and temporal stability of the intestinal microbiota in the elderly. Proc Natl Acad Sci USA. 2011; 108:4586-4591.

35. Yatsunenko T, Rey FE, Manary MJ, Trehan I, Dominguez-Bello MG, Contreras M, Magris M, Hidalgo G, Baldassano RN, Anokhin AP, Heath AC, Warner B, Reeder J, Kuczynski J, Caporaso JG, Lozupone CA, Lauber C, Clemente JC, Knights D, Knight R, Gordon JI. Human gut microbiome viewed across age and geography. Nature. 2012; 486:222-227.

36. Elliott L, Molseed LL, McCallum PD. The Clinical Guide to Oncology Nutrition. 2nd ed., 2002. p.270. 
37. Sarao LK, Arora M. Probiotics, prebiotics, and microencapsulation: a review. Crit Rev Food Sci Nutr. 2017; 57(2):344-371.

38. Vernaya M, McAdam J, Hampton MD. Effectiveness of probiotics in reducing the incidence of Clostridium difficile-associated diarrhea in elderly patients: a systematic review. JBI Database System Rev Implement Rep. 2017;15(1):140-164.

39. Bonder MJ, Kurilshikov A, Tigchelaar EF, Mujagic Z, Imhann F, Vila AV, Deelen P, Vatanen T, Schirmer M, Smeekens SP, Zhernakova DV, Jankipersadsing SA, Jaeger M, Oosting M, Cenit MC, Masclee AA, Swertz MA, Li Y, Kumar V, Joosten L, Harmsen H, Weersma RK, Franke L, Hofker MH, Xavier RJ, Jonkers D, Netea MG, Wijmenga C, Fu J, Zhernakova A. The effect of host genetics on the gut microbiome. Nat Genet. 2016;48(11):1407-1412.

40. Rothschild D, Weissbrod O, Barkan E, Kurilshikov A, Korem T, Zeevi D, Costea PI, Godneva A, Kalka IN, Bar N, Shilo S, Lador D, Vila AV, Zmora N, Pevsner-Fischer M, Israeli D, Kosower N, Malka G, Wolf BC, Avnit-Sagi T, Lotan-Pompan M, Weinberger A, Halpern Z, Carmi S, Fu J, Wijmenga C, Zhernakova A, Elinav E, Segal E. Environment dominates over host genetics in shaping human gut microbiota. Nature. 2018;555(7695):210-215.

41. Dąbrowska K, Witkiewicz W. Correlations of host genetics and gut microbiome composition. Front Microbiol. 2016 Aug 30;7:1357. doi: 10.3389/fmicb.2016.01357.

42. Chukhlovin A.B., Pankratova O.S. Opportunistic microflora at unusual sites: marker pathogens in severe posttransplant immune deficiency. Cell Ther Transplant. 2017; 6(4): 28-41.

43. Lees EA, Miyajima F, Pirmohamed M, Carrol ED. The role of Clostridium difficile in the paediatric and neonatal gut - a narrative review. Eur J Clin Microbiol Infect Dis. 2016; 35(7):1047-1057.

44. Panda S, El-Khader I, Casellas F, Lopez Vivancos J, Garcia Cors M, Santiago A, Cuenca S, Guarner F, Manichanh C. Short-term effect of antibiotics on human gut microbiota. PLoS ONE. 2014; 9(4):e95476. doi:10.1371/journal.pone.0095476

45. Xu X, Zhang X. Effects of cyclophosphamide on immune system and gut microbiota in mice. Microbiol Res. 2015;171:97-106.

46. Becattini S, Taur Y, Pamer EG. Antibiotic-induced changes in the intestinal microbiota and disease. Trends Mol Med. 2016; 22(6): 458-478.

47. Jenq RR, Taur Y, Devlin SM, Ponce DM, Goldberg JD, Ahr KF, et al. Intestinal Blautia is associated with reduced death from graft-versus-host disease. Biol Blood Marrow Transplant. 2015;21(8):1373-1383.

48. Legoff J, Resche-Rigon M, Bouquet J, Robin M, Naccache SN, Mercier-Delarue S, Federman S, Samayoa E, Rousseau C, Piron P, Kapel N, Simon F, Socié G, Chiu CY. The eukaryotic gut virome in hematopoietic stem cell transplantation: new clues in enteric graft-versus-host disease. Nat Med. 2017;23(9):1080-1085
49. Kolb H-J, Weber D, Pinto Simoes B, Holler E. Infection and GVHD. Cell Ther Transplant. 2018; 7(1):8-17.

50. Gam R, Shah P, Crossland RE, Norden J, Dickinson $\mathrm{AM}$ and Dressel R Genetic association of hematopoietic stem cell transplantation outcome beyond histocompatibility genes. Front. Immunol. 2017. 8:380. doi: 10.3389/fimmu.2017.00380.

51. Basso PJ, Fonseca MT, Bonfá G, Alves VB, Sales-Campos H, Nardini V, Cardoso CR. Association among genetic predisposition, gut microbiota, and host immune response in the etiopathogenesis of inflammatory bowel disease. 2014;47(9):727-737.

52. Andreassen OA, Desikan RS, Wang Y, Thompson WK, Schork AJ, Zuber V, Doncheva NT, Ellinghaus E, Albrecht M, Mattingsdal M, Franke A, Lie BA, Mills IG, Aukrust P, McEvoy LK, Djurovic S, Karlsen TH, Dale AM. Abundant genetic overlap between blood lipids and immune-mediated diseases indicates shared molecular genetic mechanisms. PLoS One. 2015; 10(4):e0123057. doi: 10.1371/journal. pone.0123057.

53. Kuballa P, Huett A, Rioux JD, Daly MJ, Xavier RJ Impaired autophagy of an intracellular pathogen induced by a Crohn's disease associated ATG16L1 variant. PLoS ONE. 2008; 3(10): e3391. doi:10.1371/journal.pone.0003391.

54. Matsuzawa-Ishimoto Y, Shono Y, Gomez LE, Hubbard-Lucey VM, Cammer M, Neil J, Dewan MZ, Lieberman SR, Lazrak A, Marinis JM, Beal A, Harris PA, Bertin J, Liu C, Ding Y, van den Brink MRM, Cadwell K. Autophagy protein ATG16L1 prevents necroptosis in the intestinal epithelium. J Exp Med. 2017; 214(12):3687-3705.

55. Sadabad MS, Regeling A, de Goffau MC, Blokzijl T, Weersma RK, Penders J, Faber KN, Harmsen HJM, Dijkstra G. The ATG16L1-T300A allele impairs clearance of pathosymbionts in the inflamed ileal mucosa of Crohn's disease patients. Gut. 2014, doi:10.1136/gutjnl-2014-307289

56. Salem M, Haagen Nielsen OH, Nys K, Yazdanyar S, Seidelin JB. Impact of T300A variant of ATG16L1 on antibacterial response, risk of culture positive infections, and clinical course of Crohn's disease. Clin Transl Gastroenterol. 2015; 6, e122; doi:10.1038/ctg.2015.47.

57. Kasagi S, Kawano S, Kumagai S. PD-1 and autoimmunity. Crit Rev Immunol. 2011;31(4):265-295.

58. Kristjansdottir H, Steinsson K, Gunnarsson I, Gröndal G, Erlendsson K, Alarcón-Riquelme ME. Lower expression levels of the programmed death 1 receptor on CD4+CD25+ $\mathrm{T}$ cells and correlation with the PD-1.3A genotype in patients with systemic lupus erythematosus. Arthritis Rheum. 2010;62:1702-1711.

59. Hoffmann TW, Halimi JM, Buchler M, Velge-Roussel F, Goudeau A, Najjar AA, Boulanger MD, Houssaini TS, Marliere JF, Lebranchu Y, Baron C. Association between a polymorphism in the IL-12p40 gene and cytomegalovirus reactivation after kidney transplantation. Transplantation. 2008;85:1406-1411.

60. Forconi C, Gatault P, Miquelestorena-Standley E, Noble J, Al-Hajj S, Guillemain R, Stern M, Hoffmann T, Prat L, 
Suberbielle C, Masson E, Cesbron-Gautier A, Gaudy-Graffin C, Goudeau A, Thibault G, Ivanes F, Guibon R, Kazma I, Lebranchu Y, Büchler M, Magnan A, Halimi JM, Baron C. Polymorphism in programmed cell death-1 gene is strongly associated with lung and kidney allograft survival in recipients from CMV-positive donors J Heart Lung Transplant. 2017;36(3):315-324.

61. Santos N, Rodríguez-Romanos R, de la Cámara R, Brunet S, Nieto JB, Buño I, Martínez C, Jiménez-Velasco A, Vallejo C, González M, Solano C, Ferrá C, Sampol A, Pérez-Simón JA, López-Jiménez J, Díez JL, Gallardo D. PD-1 genotype of the donor is associated with acute graft-versus-host disease after HLA-identical sibling donor stem cell transplantation. Ann Hematol. 2018; 97(11):2217-2224.

62. Mansur A, Hinz J, Hillebrecht B, Bergmann I, Popov AF, Ghadimi M, Bauer M, Beissbarth T, Mihm S. Ninety-day survival rate of patients with sepsis relates to programmed cell death 1 genetic polymorphism rs11568821. J Invest Med. 2014; 62(3):638-643.

63. Sivan A, Corrales L, Hubert N, Williams JB, Aquino-Michaels K, Earley ZM, Benyamin FW, Lei YM, Jabri B, Alegre ML, Chang EB, Gajewski TF. Commensal Bifidobacterium promotes antitumor immunity and facilitates anti-PD-L1 efficacy. Science. 2015;350(6264):1084-1089.

64. Monedero V, Buesa J, Rodríguez-Díaz J. The interactions between host glycobiology, bacterial microbiota, and viruses in the gut. Viruses. 2018;10(2). pii:E96. doi: 10.3390/ v10020096.

65. Günaydın G, Nordgren J, Sharma S, Hammarström L. Association of elevated rotavirus-specific antibody titers with HBGA secretor status in Swedish individuals: The FUT2 gene as a putative susceptibility determinant for infection. Virus Res. 2016;211:64-68. doi: 10.1016/j.virusres.2015.10.005

66. Vilor-Tejedor N, Medina-Gomez C, Bonilla C, Ahluwalia TS, Bacelis J, Bradfield JP, Tiesler CM, Rivadeneira F, Ring S, Vissing NH, Fink NR, Jugessur A, Mentch FD, Ballester F, Kriebel J, Kiefte-de Jong JC, Wolsk HM, Llop S, Thiering E, Beth SA, Timpson NJ, Andersen J, Schulz H, Jaddoe VW, Evans DM, Waage J, Hakonarson H, Grant SF, Jacobsson B,Bønnelykke K, Bisgaard H, Davey Smith G, Moll HA, Heinrich J, Estivill X, Sunyer J. A genome-wide association meta-analysis of diarrhoeal disease in young children identifies FUT2 locus and provides plausible biological pathways. Hum Mol Genetics, 2016;25(18):4127-4142.

67. Tong M, McHardy I, Ruegger P, Goudarzi M, Kashyap PC, Haritunians T, Li X, Graeber TG, Schwager E, Huttenhower C, Fornace AJ Jr, Sonnenburg JL, McGovern DP, Borneman J, Braun J. Reprograming of gut microbiome energy metabolism by the FUT2 Crohn's disease risk polymorphism. ISME J. 2014, 8(11): 2193-2206.

68. Turpin W, Bedrani L, Espin-Garcia O, Xu W, Silverberg MS, Smith MI, Guttman DS, Griffiths A, Moayyedi P, Panaccione R, Huynh H, Steinhart H, Aumais G, Shestopaloff K, Dieleman LA, Turner D, Paterson AD, Croitoru K. FUT2 genotype and secretory status are not associated with fecal microbial composition and inferred function in healthy subjects. Gut Microbes. 2018 ;9(4):357-368.
69. Holler E, Landfried K, Meier J, Hausmann M, Rogler $\mathrm{G}$. The role of bacteria and pattern recognition receptors in GVHD. Int J Inflam. 31 October 2010:814326. doi: 10.4061/2010/814326.

70. Landfried K, Bataille F, Rogler G, Brenmoehl J, Kosovac K, Wolff D, Hilgendorf I, Hahn J, Edinger M, Hoffmann P, Obermeier F, Schoelmerich J, Andreesen R, Holler E. Recipient NOD2/CARD15 status affects cellular infiltrates in human intestinal graft-versus-host disease. Clin Exp Immunol. 2010;159(1):87-92.

71. Hrnčířová L, Krejsek J, Šplíchal I, Hrnčíř T. Crohn's disease: a role of gut microbiota and Nod2 genepolymorphisms in disease pathogenesis. Acta Medica (Hradec Kralove). 2014;57(3):89-96.

72. Grube M., Brenmoehl J, Rogler G., Hahn J, Herr W, Holler E. Donor nucleotide-binding oligomerization-containing protein 2 (NOD2) single nucleotide polymorphism 13 is associated with septic shock after allogeneic stem cell transplantation. Biol Blood Marrow Transplant. 2015; 21:13991404.

73. Liu R, Mo YY, Wang HL, Tan Y, Wen XJ, Deng MJ, Yan $\mathrm{H}$, Li L. The relationship between toll-like receptor 4 gene rs4986790 and rs4986791 polymorphisms and sepsis susceptibility: a meta-analysis. Sci Rep. 2016;6:38947.

74. Li D, Achkar J-P, Haritunians T, Jacobs JP, Hui KY, D'Amato M, Brand S, Radford-Smith G, Halfvarson J, Niess J-H, Kugathasan S, Büning C, Schumm LP, Klei L, Ananthakrishnan A, Aumais G, Baidoo L, Dubinsky M, Fiocchi C, Glas J, Milgrom R, Proctor DD, Regueiro M, Simms LA, Stempak JM, Targan SR, Törkvist L, Sharma Y, Devlin B, Borneman J, Hakonarson H, Xavier RJ, Daly M, Brant SR, Rioux JD, Silverberg MS, Cho JH, Braun J, McGovern DP, Duerr RH, A pleiotropic missense variant in SLC39A8 is associated with Crohn's disease and human gut microbiome composition. Gastroenterology. 2016, doi: 10.1053/j.gastro.2016.06.051.

75. Karin M, Jobin C, Balkwill F. Chemotherapy, immunity and microbiota -a new triumvirate? Nat Med. 2014; 20(2): 126-127.

76. Yu T, Guo F, Yu Y, Sun T, Ma D, Han J, Qian Y, Kryczek I, Sun D, Nagarsheth N, Chen Y, Chen H, Hong J, Zou W, Fang JY. Fusobacterium nucleatum promotes chemoresistance to colorectal cancer by modulating autophagy. Cell. 2017;170(3):548-563.

77. Viaud S, Saccheri F, Mignot G. The intestinal microbiota modulates the anticancer immune effects of cyclophosphamide. Science. 2013; 342(6161): 971-976.

78. Pflug N, Kluth S, Vehreschild JJ, Bahlo J, Tacke D, Biehl L, Eichhorst B, Fischer K, Cramer P, Fink AM, von Bergwelt-Baildon M, Stilgenbauer S, Hallek M, Cornely OA, Vehreschild MJ. Efficacy of antineoplastic treatment is associated with the use of antibiotics that modulate intestinal microbiota. Oncoimmunology, 2016, 5(6), e1150399; DOI: 10.1080/2162402X.2016.1150399

79. Peled JU, Devlin SM, Staffas A, Lumish M, Khanin R, Littmann ER, Ling L, Kosuri S, Maloy M, Slingerland JB, Ahr KF, Porosnicu Rodriguez KA, Shono Y, Slingerland AE, Do- 
campo MD, Sung AD, Weber D, Alousi AM, Gyurkocza B, Ponce DM, Barker JN, Perales MA, Giralt SA, Taur Y, Pamer EG, Jenq RR, van den Brink MRM. Intestinal microbiota and relapse after hematopoietic-cell transplantation. J Clin Oncol. 2017; 35(15): 1650-1659. doi: 10.1200/JCO.2016.70.3348.

80. Kanauchi O, Fukuda M, Matsumoto Y, Ishii S, Ozawa T, Shimizu M, Mitsuyama K, Andoh A. Eubacterium limosum ameliorates experimental colitis and metabolite of microbe attenuates colonic inflammatory action with increase of mucosal integrity. World J Gastroenterol. 2006;12:1071-1077

81. Vitetta L, Manuel R, Zhou JY, Linnane AW, Hall S, Coulson S. The overarching influence of the gut microbiome on end-organ function: the role of live probiotic cultures. Pharmaceuticals (Basel). 2014; 7(9):954-989

82. Cammarota G, Pecere S, Ianiro G, Masucci L, Curro D. Principles of DNA-based gut microbiota assessment and therapeutic efficacy of fecal microbiota transplantation in gastrointestinal diseases. Dig Dis. 2016;34:279-285.

83. Kakihana K, Fujioka Y, Suda W, et al. Fecal microbiota transplantation for patients with steroid-resistant acute graft-versus-host disease of the gut. Blood. 2016 128:20832088;

84. van Lier YF, de Groot PF, Nur E, Zeerleder SS, Nieuwdorp M, Blom B, Hazenberg MD. Fecal microbiota transplantation as safe and successful therapy for intestinal graftversus-host disease. Blood. 2017;130:1986.

85. Goloschapov O, Kucher M, Suvorova M, Klementeva R, Shcherbakov A, Shvetcov A, Chukhlovin A, Afanasyev B. Clinical outcomes of fecal microbiota transplantation for overcoming multidrug resistant infection complications after haploidentical hematopoietic stem cell transplantation // Proc. 43 ${ }^{\text {rd }}$ Annual EBMT Meeting, Marseilles. France. 2017: P.340.

86. Kucher MA, Goloschapov OV, Moiseev IS, Afanasyev BV. Fecal microbiota transplantation as a method to treat complications after hematopoietic stem cell transplantation. Cell Ther Transplant. 2017;6(1):20-28.

87. Columpsi P, Sacchi P, Zuccaro V, Cima C, Sarda C, Mariani M, Gori A, Bruno R. Beyond the gut bacterial microbiota: the gut virome. J. Med. Virol. 2016; DOI 10.1002/jmv

88. Tamburini FB, Sherlock G, Bhatt AS. Transmission and persistence of crAssphage, a ubiquitous human-associated bacteriophage. BioRxiv (a Cold Spring Lab preprint server), doi: https://doi.org/10.1101/460113.

89. Oude Munnink BBO, van der Hoek L. Viruses causing gastroenteritis: the known, the new and those beyond. Viruses 2016; 8, 42; doi:10.3390/v8020042

90. Fischer SA. Emerging viruses in transplantation: there is more to infection after transplant than CMV and EBV. Transplantation. $2008 ; 86(10): 1327-1339$.

91. Legoff J, Feghoul L, Mercier-Delarue S, Dalle JH, Scieux C, Chérot J, de Fontbrune FS, Baruchel A, Socié G, Simon F. Broad-range PCR-electrospray ionization mass spectrome- try for detection and typing of adenovirus and other opportunistic viruses in stem cell transplant patients. J Clin Microbiol. 2013 51(12):4186-4192.

92. Ott SJ, Waetzig GH, Rehman A, Moltzau-Anderson J, Bharti R, Grasis JA, Cassidy L, Tholey A, Fickenscher H, Seegert D, Rosenstiel P, Schreiber S. Efficacy of sterile fecal filtrate transfer for treating patients with Clostridium difficile infection. Gastroenterology. 2017;152(4):799-811.

93. Górski A, Jonczyk-Matysiak E, Miedzybrodzki R, Weber-Dabrowska B, Borysowski J. Phage transplantation in allotransplantation: possible treatment in graft-versus-host disease? Front Immunol. 2018; 9:941. doi: 10.3389/fimmu.2018.00941

94. Zuo T, Wong SH, Lam K, Lui R, Cheung K, Tang W, Ching JYL, Chan PKS, Chan MCW, Wu JCY, Chan FKL, Yu J, Sung JJY, Ng SC. Bacteriophage transfer during faecal microbiota transplantation in Clostridium difficile infection is associated with treatment outcome. Gut. 2017; 67(4):634-643. 


\title{
Микробиом кишечника при трансплантации гемопо- этических стволовых клеток: факторы, зависящие от пациента и терапии
}

\author{
Олег В. Голощапов, Максим А. Кучер, Алексей Б. Чухловин \\ НИИ детской онкологии, гематологии и трансплантологии им. Р. М. Горбачевой; Первый Санкт-Петербургский \\ государственный медицинский университет им. И. П. Павлова, Санкт-Петербург, Россия
}

\section{Резюме}

Интенсивная цитостатическая терапия применяется в качестве стандартной терапии злокачественных новообразований гемопоэтической системы. Кондиционирующая терапия перед трансплантацией гемопоэтических стволовых клеток (ТГСК) приводит как к острому клеточному иммунодефициту, так и к тяжелым нарушениям кишечного эпителия, а массивная антибактериальная терапия ведет к глубоким нарушениям состава кишечной микрофлоры. Целью настоящего обзора было уточнение генетических факторов, внешних воздействий и терапевтических факторов, вызывающих изменения кишечной микробиоты в процессе интенсивной цитостатической терапии, обозначение возможных подходов к нормализации кишечного микробиома при ТГСК. Обсуждаются ранние эксперименты с безмикробными животными, описываются общепринятые взгляды на «нормальную» микробиоту кишечника человека, ее вариабельность и изменения, зависящие от возраста, диеты и генетической предрасположенности по основным классам кишечной микробиоты, т. е., анаэробных Clostridia, и более аэробных Bacteroides, Proteobacteria. Измененный состав и снижение биоразнообразия кишечной микробиоты рассматривается в качестве регулярного следствия цитостатической и антибактериальной терапии в период ТГСК. Роль порозности кишечной стенки и соответствующие эффекты на иммунную систему организма-хозяина рассматриваются в аспекте риска реакции «трансплантат против хозяина», а также возможных антирецидивных эффектов при лейкозах, связанных с изменениями состава кишечной микробиоты. Обсуждаются некоторые гены, влияющие на кишечную микробиоту, например - влияние ATG16L1, PD-1, FUT2 и других генных вариантов, которые могут влиять на эффективность ТГСК.
Потенциальная роль многочисленных кишечных вирусов («вирома») известна в значительно меньшей степени, в связи с относительной нехваткой данных, полученных путем секвенирования следующего поколения (NGS) бактериофагов и вирусов эукариотических клеток.

В заключение отмечено, что многие факты о кишечной микробиоте требуют особой оценки у человека при его лечении. Проведен ряд работ, направленных на коррекцию измененной кишечной микробиоты при различных кишечных синдромах, в том числе с использованием отдельных пробиотических штаммов Lactobacteria, Bifidobacteria, Faecalibacterium prausnitzii, и в последнее время - трансплантации фекальной микробиоты, в том числе и при дисбиозе после ТГСК. Основная проблема состоит в том, что при анализе сложных взаимодействий бактериальной микробиоты в клинических условиях мы еще не знаем, какие именно микробные виды (или классы) продуцируют эффекторные молекулы, которые модифицируют иммунный ответ, ведущий к тяжелой РТПХ или изменяющий противоопухолевый ответ иммунотерапии. Для соответствующих сравнений со здоровыми людьми следует устанавливать нормальные области значений для конкретных классов кишечной микробиоты в различных возрастных группах.

\section{Ключевые слова}

Микробиом, кишечный, кишечные бактерии, виром, трансплантация гемопоэтических стволовых клеток, цитостатическая терапия, антибактериальное лечение, подавление микрофлоры, трансплантация кишечной микробиоты. 